\title{
Rangeland management and climate hazards in drylands: dust storms, desertification and the overgrazing debate
}

\author{
Nick Middleton ${ }^{1}$ (D)
}

Received: 6 April 2016/Accepted: 21 September 2016/Published online: 11 October 2016

(C) The Author(s) 2016. This article is published with open access at Springerlink.com

\begin{abstract}
This paper examines the theory and supporting evidence for links between desertification, drought and dust storms with a particular focus on studies undertaken in and around the Gobi Desert. Overgrazing of rangeland by pastoralists has been the most commonly cited cause of desertification in global drylands for more than 30 years, but the evidence supporting this link is not always convincing. Nonetheless, overgrazing, desertification and dust storms are frequently connected, regardless. Drought is another wellknown and important driver of vegetation cover change. Distinguishing between vegetation cover adversely affected by drought and that reduced by grazing is imperative for policy makers because identifying the incorrect driver of vegetation change risks the development of inappropriate policy.
\end{abstract}

Keywords Rangeland · Pastoralism · Desertification · Dust storms · Drought - Gobi Desert

\section{Introduction}

Deserts and semideserts, commonly referred to as drylands, are defined by their aridity: their water resources are limited because precipitation is characteristically scarce and unreliable and evaporation is typically high. These areas are important global environments because they cover more than $40 \%$ of the world's land surface and are home to over 2 billion people (Middleton and Thomas 1997; Safriel et al. 2005). Drylands are found on every continent, but most drylands are located in developing countries and $90 \%$ of dryland inhabitants live in these countries (Safriel et al. 2005). Globally, about half of all dryland inhabitants are poor, about a billion people in total, dubbed the 'forgotten billion' because they have habitually been neglected in development processes (Middleton et al. 2011).

Nick Middleton

nicholas.middleton@st-annes.ox.ac.uk

1 St Anne's College, University of Oxford, Oxford, UK 
These people are involved in many occupations, but herding livestock is the most extensive form of land use. Indeed, desert-marginal rangelands support about $50 \%$ of the world's livestock (Allen-Diaz et al. 1996) and pastoralism remains the only viable livelihood for many rural dryland populations. Where comprehensive estimates have been made, pastoralism has been shown to contribute significantly to the GDP of dryland developing country economies: for example, about $10 \%$ of GDP in Mali, $20 \%$ in Kyrgyzstan and $30 \%$ in Mongolia (WISP 2008). In these and many other countries, no other drylands production system is more productive or supports as large a human population.

Drylands in general are also important to the Earth system for a range of key resources and other ecosystem services. Some dryland vegetation communities, such as the temperate grasslands, rival tropical rainforests for their species richness (Dengler et al. 2014), while their regulating services include important stores of carbon and effects on regional and even global climate (Yatagai and Yasunari 1995).

Pastoralists in drylands inevitably depend directly upon a highly variable natural resource base for their livelihoods, and this variability is driven primarily by climatic factors that present a range of natural hazards (Middleton and Sternberg 2013). Principal among these is the variability of precipitation. Rainfall totals often vary greatly from year to year and over short distances, typically producing 'resource mosaics' of water, nutrients, biodiversity and productivity. Long experience of coping with the vagaries of their environment has enabled traditional pastoralists to develop numerous strategies for managing risk and variability. Patterns of pastoral mobility underpin local adaptive capacities, although herders remain vulnerable to natural perturbations, particularly those driven by the highly variable climate regimes.

Rangeland management sometimes produces unintended outcomes, and one frequently cited result of mismanagement by pastoralists is overgrazing, leading to a loss of vegetation cover and accelerated soil erosion, two common forms of land degradation, or desertification as it is known in drylands (Middleton and Thomas 1997). However, both vegetation cover change and accelerated erosion — by wind and/or water-can also result from solely climatic drivers, without the influence of any rangeland mismanagement, and the issue of overgrazing is controversial (Vetter 2005; Reid et al. 2014). Different views on the extent of overgrazing in drylands have in turn divided opinions about the sustainability of pastoralism in general, with consequent implications for dryland development policies.

The aim of this paper is to examine the theory and empirical evidence for links between desertification by overgrazing, drought and dust storms with a particular focus on the Gobi Desert, a major world dryland area where mobile pastoralism has a very long history stretching back well over a 1000 years (Lattimore 1938; Di Cosmo 1994; Endicott 2012). This review is followed by assessments of how contemporary governments in China and Mongolia view pastoralism and rangeland use and their policies towards them.

\section{Dust storms, desertification and drought}

The entrainment and transport of soil dust by wind is a common phenomenon in many drylands, and dust storms are recognised as of increasing environmental and human significance at local and global levels. As a hazard, desert dust has serious implications for human society via impacts on health, agriculture, transport and communications (Goudie and Middleton 2006). In and around the Gobi Desert, much attention has been devoted to challenges associated with dust transported over long distances to major regional cities, 
including Beijing (Liu et al. 2014), Seoul and Tokyo (Kashima et al. 2016). The long-term beneficial aspects of dust deposition are also evident in China on the Loess Plateau, an important farming region for many centuries (Huang et al. 2002).

Dust storms occur when strong, turbulent winds blow over dry, unconsolidated, finegrained surface materials where vegetation cover is sparse if not altogether absent. Many dust sources are naturally devoid of vegetation thanks to a dryland climate. For instance, the world's largest source of desert dust is in the Bodélé Depression, a very sparsely populated area of Chad with plentiful supplies of fine-grained sediments provided by an ancient lake bed (Bristow et al. 2009). Elsewhere, dust is entrained from environments that have become susceptible to wind action through human influence. These situations include lake beds that have been desiccated due to society's use of water, as in the Aral Sea in Central Asia (Issanova et al. 2015), and agricultural fields left bare after harvests and/or ploughing, as during the notorious Dust Bowl years on the Great Plains of the USA (McLeman et al. 2014). The relative contribution of sources significantly influenced by human action to global dust emissions is a subject for debate with estimates varying from $50 \%$ (Tegen et al. 1996) to insignificant (Prospero et al. 2002).

Vegetation protects soil surfaces from wind erosion. One outcome of the US Dust Bowl was a considerable increase in research into how wind erosion can be controlled in agricultural areas, and the importance of vegetation was quickly realised. Indeed, the establishment and maintenance of sufficient vegetative cover is often referred to as the 'cardinal rule' for controlling wind erosion (Skidmore 1986).

A number of other human activities - besides cultivation - can result in the degradation and reduction of vegetation cover, with an increase in wind erosion a possible outcome. These include logging, the use of fire, clearance for urban development and roads, and the effects of intensive grazing by domestic livestock.

The overuse of rangelands, caused by allowing too many animals or inappropriate types of animals to graze, is frequently cited as the most widespread cause of desertification, defined in the UN Convention to Combat Desertification (UNCCD) as 'land degradation in arid, semiarid, and dry sub-humid areas resulting from various factors, including climatic variations and human activities'. At the global scale, it is estimated that up to $73 \%$ of the world's rangelands may be degraded (Lund 2007). Local estimates suggest that $90 \%$ of the natural grasslands in China (Yang et al. 2005) and $70 \%$ in Mongolia (Regdel et al. 2012) are degraded.

Rangeland degradation can take many forms, including impacts on flora, fauna and soil properties. Variables that have been used as indicators to assess degradation on rangelands include vegetation diversity, total vegetation cover, shrub cover, grass cover, forb cover, total vegetation biomass, belowground biomass, seedling survival, rodent species richness, rodent species diversity, cryptogamic crust cover, litter cover, litter biomass, soil bulk density, infiltration rate, soil organic matter, level of soil carbon and soil erosion rate. All of these indicators are interrelated in numerous ways, but some variables have a more immediate and obvious effect on susceptibility to wind erosion (total vegetation cover, cryptogamic crust cover) than others. Of course, as the UNCCD definition of desertification allows, rangeland degradation, and hence all these indicators used to assess degradation, can also be affected by natural, abiotic factors, notably variable rainfall.

Drought is the principal natural hazard faced by communities living in most drylands, and it can wreak significant, widespread and long-lasting damage on herding communities via declines in forage and water availability. Droughts frequently result in huge losses of livestock for pastoralists, most notably in Africa (Huho et al. 2011). The negative impact drought has on vegetation cover also has effects on soil erodibility, often leading to 
enhanced dust storm activity (Middleton 1985; McTainsh et al. 2005). It is not always easy to determine the relative importance of natural and human-induced drivers of vegetation loss and any consequent soil loss. Indeed, different interpretations of vegetation change drivers have created considerable controversy and confusion in the desertification literature, particularly on the margins of the Sahara (Tucker et al. 1991; Nicholson et al. 1998) but also more recently in the Gobi (Piao et al. 2005; Sternberg et al. 2015).

\section{The overgrazing debate}

The impact of grazing by domestic livestock in rangelands has also generated considerable debate in recent decades. Much of the discussion has revolved around different ideas of rangeland dynamics in general and two paradigms in the ecology and management of rangelands in particular. On the one hand is a model based on the largely static 'climax community' of Clementsian succession (Clements 1916). This is an equilibrium model that stresses the importance of biotic feedbacks on vegetation composition, cover and productivity. Principal among these feedbacks are those driven by livestock populations and their density in any particular area. Range management under this model therefore focuses on stocking rates, carrying capacity and range condition assessment.

By contrast, the more dynamic non-equilibrium view of rangelands has it that vegetation condition is driven primarily by stochastic abiotic factors, notably variable rainfall. This results in highly variable and unpredictable primary production. Under this model, livestock populations are thought to have negligible feedback on the vegetation as their numbers rarely reach equilibrium with a resource base that is constantly fluctuating.

There are studies reported in the scientific literature to support both approaches to rangeland dynamics. Further, as Jones (2000) points out, the results of studies conducted in different plant communities, or at different sites representing the same community, frequently contradict one another. He cites surveys of grazing impact in an arid shrub/ bunchgrass community in two adjacent valleys in the US southwest, one survey concluding that vegetative cover was greater in ungrazed areas (Johansen and St. Clair 1986) and the other finding that total vegetation cover was greater in grazed areas (Brotherson and Brotherson 1981). The lack of consensus regarding potentially detrimental effects of livestock grazing on rangelands is epitomised in two papers from Sahelian Africa. Hein (2006) concludes that a 10-year enclosure experiment in Senegal shows high grazing pressure negatively affects rangeland productivity, but Retzer (2006) reanalyses the same data to show that the vegetation on the 'high grazing' site has great resilience and produced greater forage for 2 years after a major drought than the less intensively grazed site.

Discussion about the relative merits of the two approaches to understanding rangeland dynamics has been intensified when the debate progresses to encompass views on how best to manage grazing in rangelands. In this context, both natural and social sciences are represented since the focus is on the sustainability of pastoralist land use. Views on the sustainability of grazing have also diverged, largely reflecting the different ideas on rangeland ecology. One approach adopts the equilibrium model and follows the arguments put forward in Hardin's (1968) Tragedy of the Commons idea. This view argues that traditional pastoralists frequently graze their livestock in unsustainable numbers because they pursue their short-term survival at the expense of the long-term conservation of commonly owned natural resources. The opposing view adopts a non-equilibrium understanding of rangelands, in which grazing has only a marginal influence on vegetation 
dynamics. Under this philosophy, a traditional 'opportunistic' grazing strategy matches the stocking rate to the available forage in any particular year.

In the former approach, traditional pastoralism is seen as unsustainable and in need of modernisation (Lamprey 1983). The latter view leads to the opposite conclusion: pastoralist land use practices are an effective and sustainable response to the highly variable natural environment (Behnke et al. 1993).

Although views on the sustainability of grazing in rangelands have often become polarised, matching the opposing paradigms of rangeland ecology, recent studies indicate that it is not an either/or issue. Most arid and semiarid rangelands encompass elements of both equilibrium and non-equilibrium approaches and both grazing and variable rainfall are important drivers of vegetation dynamics on different temporal and spatial scales (Vetter 2005; Gillson and Hoffman 2007). Hence, any sustainable approach to management must take account of temporal variability and spatial heterogeneity (Joly et al. 2012).

Of course there are also many nuances to a debate that is frequently presented in simple dualistic terms. The notion that a certain level of grazing has the effect of enhancing plant productivity has a considerable history, although plants respond to a whole suite of environmental factors, and the variety of plant responses is subject to the constraints of plant genetics, developmental stage and the plant tissues affected (McNaughton 1983). Further, different plants respond to being eaten by animals in different ways (Matches 1992). Similarly, different species of domestic livestock have different forage demands and foraging behaviours and can therefore reasonably be expected to have different impacts on vegetation communities. One form of vegetation change that is commonly associated with heavy grazing in some grasslands is an increase in biomass and abundance of woody plant species that are frequently thorny or unpalatable, with the suppression of herbaceous plant cover. This bush encroachment is another widely recognised form of rangeland degradation (D'Odorico et al. 2012).

The direct defoliation effects of grazing or browsing are just one set of impacts associated with livestock. Soil surfaces and soil profiles are materially affected by compaction caused by animal trampling, and excretion by grazing animals has impacts on vegetation, soils and surface waters (Bilotta et al. 2007). The time and space scales of observations on which we base our understanding also have consequences. One study in the Eastern Cape, South Africa concluded that historical land use change was critical: particularly intense erosion was associated with cultivated land that had been abandoned and reverted to grazing (Rowntree et al. 2004). In a global review of ecosystem sensitivity to grazing by large herbivores, Milchunas and Lauenroth (1993) concluded that an evolutionary history involving grazing animals and the local environment was a critical factor in determining negative impacts of grazing on productivity.

\section{Desertification in the Gobi Desert}

The Gobi is one of the world's largest deserts although, like many deserts, its boundaries are dynamic and ill-defined. Establishing the extent of any particular desert is complicated by the use of localised names for areas within large deserts (Middleton 2009), but this paper follows Sternberg et al. (2015) by including within the Gobi a large part of Mongolia and contiguous desert areas in northern China known locally as the Tengger, Ordos, $\mathrm{Mu}$ Us, Badain Jaran, Junggar, Gurbantunggut, Qubqi and Otindag. 
There are many reports in the literature indicating that desertification is a serious issue in the Gobi (Fullen and Mitchell 1994; Yang et al. 2005; Johnson et al. 2006; Regdel et al. 2012; Qi et al. 2013). Among the causes, an increase in the number of domestic livestock is frequently cited as a major driver of degradation in Mongolia (Sasaki et al. 2008; Hilker et al. 2014) and overgrazing also features as a prominent reason for desertification in China (Zhao et al. 2005; Han et al. 2008).

However, not all agree about the extent or severity of desertification in the Gobi or about the importance of the human impact. In a review, Wang et al. (2008) conclude that there is surprisingly little unassailable evidence to support the claim that desertification in China is primarily due to human impacts. Similarly, Khishigbayar et al. (2015) suggest that many claims about rangeland degradation in Mongolia have weak empirical support. There are also numerous studies that emphasise abiotic drivers of vegetation change, particularly the significance of the precipitation regime (Fernández-Giménez and Allen-Diaz 2001; Stumpp et al. 2005; Jeong et al. 2011). Assessments of rangeland condition and desertification also vary widely. In Mongolia, the most commonly cited proportion of rangelands degraded is $70 \%$, as cited above, but Addison et al. (2012) point out that a variety of scales, indicators and sampling regimes have thrown up estimates ranging from 9 to $90 \%$ of the entire country.

Of course the UNCCD definition of desertification cited above means that rangeland degradation can be the result of both climatic variability and human activities (e.g. Liu et al. 2013), perhaps acting in tandem and not necessarily at the same time. However, some of the disagreements in the literature may also be the result, at least partly, of the methodology used. Khishigbayar et al. (2015) point out that there are plenty of remote sensing studies reporting widespread degradation of Mongolian rangelands, as indeed there are in China, but very few long-term field studies of vegetation responses to shifts in climate and stocking densities, a general observation that applies to most other rangelands. Yang et al. (2005) also criticise the use of some remotely sensed data sources in assessments of desertification in China, as well as highlighting the uncertainty of baseline assessments. Interestingly, Zemmrich (2007) assesses the impact of grazing in Mongolia's arid desert steppe and finds that grazing influence increases with decreasing spatial scale of analysis.

\section{Policies to combat desertification}

Despite the difficulties and disagreements surrounding our understanding of change in dryland landscapes, regions that are inherently variable in biophysical terms and prone to stochastic disturbances, there remains a prevalent view of desertification as being widespread and of overgrazing as a core cause in both Mongolia and China, a perspective that has informed policies. The design of policy responses, particularly many of those applied to Chinese grasslands, incorporates a specific aim of reducing the generation of dust and sand storms.

Recent large-scale projects in China that target rangelands, at least in part, include the Pasture to Grassland programme implemented in all of China's pastoral areas from 2003 and the Beijing-Tianjin Sand Source Control programme in Inner Mongolia from 2001 (Dalintai et al. 2011). Under Pasture to Grassland, grazing on existing pastures is banned (either permanently, for a few years, or seasonally) in specific zones; Beijing-Tianjin Sand Source Control involves a mix of measures, including grazing prohibition or rotation or 
rest, and the conversion of cropland to forest or grassland (though not for grazing). One of China's most ambitious projects to combat desertification and control dust storms is an afforestation project, the Three Norths Forest Shelterbelt programme (also known as the Great Green Wall or GGW), which was launched in 1978 and is not scheduled to be complete until 2050 (Wang et al. 2010a). Additional 'ecological restoration projects' are focused on other land uses associated with soil erosion problems, such as the Grain-forGreen programme designed to convert cropland to forest and grassland (Lei et al. 2012).

Assessments of the efficacy of these projects in remediating desertification in general, and specifically in preventing dust storms, do not all agree. Tan and Li (2015) show that the GGW programme greatly improved vegetation cover, as measured by the normalised difference vegetation index (NDVI), and effectively reduced dust storm intensity in northern China. A similar conclusion about vegetation is reached by Zhang et al. (2016) in their assessment of several afforestation programmes, although Wu et al. (2013) found that vegetation response to the first 10 years of the Beijing-Tianjin Sand Source Control programme was distinctly patchy. After a decade-long fencing experiment to assess the impacts of a grazing ban on sandy rangelands in Inner Mongolia, Su et al. (2015) warn that one unexpected outcome is likely to be bush encroachment, often shown in NDVI studies as a form of greening. They conclude that some degree of grazing by livestock may provide critical ecosystem services by regulating woody plant encroachment.

Other researchers point to warmer temperatures and greater rainfall as being more important drivers of greening trends in northern China (Piao et al. 2007; Sternberg et al. 2015), and the value of large-scale afforestation, a primary tool for controlling desertification and soil erosion in China, has been questioned due to low tree survival rates. Cao (2008) argues that inappropriate project design—-planting trees in rangelands—has resulted in declining soil moisture content and a worsening of wind erosion in China's dryland regions. Qu et al. (2011) emphasise the significance of government policies aimed at controlling natural resource degradation in rural China for the success of economic policies introduced since 2004 to stimulate rural incomes. However, despite the importance of realising the 'new socialist countryside', these authors also conclude that degradation of natural grassland and wind erosion have become much more severe in recent decades. That said, Huang et al. (2013) report that rangeland restoration programmes have resulted in a systematic increase in the area of grassland in most northern and western regions and that restored, ungrazed grasslands have contributed to intensified primary production in these dryland areas.

Tree planting initiatives have also been promoted in Mongolia, where state-sponsored planting programmes date back at least to the 1970s in many parts of the country, including forestry offices in the Gobi region (Dorjsuren and Sainbayar 2004). A major new national initiative was launched in the Gobi in 2005, when the government pledged considerable investment for a large-scale planting scheme designed to reduce dust storms and mitigate the impacts of desertification. The scheme, variously known as the Great Green project or the Korea-Mongolia Greenbelt Project (since planting sites are co-funded with Korean bilateral aid money), is intended to extend east-west across the country for $2500 \mathrm{~km}$ with a width of at least $600 \mathrm{~m}$. High initial success rates have been reported, but historical survival rates of tree planting in the Gobi over the longer term have been minimal (Mühlenberg et al. 2006).

A number of dust storm studies in the Gobi region point to rainfall and other climatic drivers of change as being of greatest importance. Lee and Sohn (2011) found that most dust source areas in China experienced a continuous decrease over a 34-year data period (1974-2007) which they attribute to enhanced precipitation and its effects on soil moisture 
and surface vegetation. Fan et al. (2014) emphasise the effect of earlier spring vegetation green-up in suppressing dust storm activity. Zhu et al. (2008) refer to a weakening of the westerly jet stream in northern China and Mongolia to explain the declining trend. Lee and Sohn also conclude that an increase in dust occurrence after the mid-1990s over eastern Mongolia and Chinese Inner Mongolia may be largely influenced by drought conditions and associated soil moisture change, while Kurosaki et al. (2011) emphasise the importance of vegetation residue from the previous year and its effect on erodibility in explaining the recent increase in dust outbreaks over East Asia. Forty years of dust event data from Seoul in South Korea show an increasing trend from the early 1980s (Kim 2008) which is attributed to an eastward shift in the regional source of dust (from Mongolia to Manchuria) but also to changes in upper-level synoptic transport patterns. Intensified atmospheric circulation and an associated increase in wind speed as well as changes in snow cover, soil moisture and potential evaporation rates throughout Inner Mongolia and Manchuria are considered to be the main causes of the increasing number of dusty days in Korea. No mention is made of policies to control desertification or dust storms in any of these dust storm papers.

\section{Discussion}

The deserts and semideserts of China and Mongolia are well established as significant sources of desert dust, although on the global scale the most important regional source is not the Gobi but the Taklamakan Desert (Goudie and Middleton 2006), located further west in the Tarim Basin. The regional preeminence of the Taklamakan is confirmed by many studies (e.g. Shao and Wang 2003; Zhang et al. 2003), but its standing as a source of long-distance dust transport is debated (see Bory et al. 2003; Zhang et al. 2008). Several specific sources within the Gobi are also identified. Prominent among these are the Badain Jaran (Zhang et al. 2003), the numerous alluvial fans along the Hexi Corridor in Gansu province (Derbyshire et al. 1998) and the Inner Mongolia Plateau with adjacent areas of south-eastern Mongolia (Wang et al. 2004).

The standing of rangelands in this picture remains unclear. There are many uncertainties and gaps in our knowledge about how grasslands may act as dust sources (Shinoda et al. 2011). In a rare field experiment, Hoffmann et al. (2008) found that grazing intensity was a significant factor affecting wind erosion on plots in the Xilingele grassland, Inner Mongolia, but that these local sources provided just $5 \%$ of the total horizontal dust flux and some of this was material recently deposited from distant sources and re-emitted. However, areas with significant livestock populations (the lowlands of the eastern Mongolian Plateau, including Dornogovi province in Mongolia, and the Otindag and Horqin sandy lands of Inner Mongolia) were identified by Zhang et al. (2008) as the greatest source of regional dust emissions in their assessment based on satellite imagery during the period 2000-2006. Zhang et al. (2003) also highlight Otindag and Horqin, along with the Mu Us Desert, as areas with increased dust emissions over the previous 20 years, but dismiss them as minor sources, concluding that efforts to reduce desertification in these areas have had little effect on Asian dust emissions.

These uncertainties are of course compounded by the doubts surrounding the overall extent and severity of desertification in the Gobi, the debate over the relative importance of biotic vs abiotic drivers of vegetation dynamics in rangelands, and the sustainability of pastoralism in general. All these factors are to some extent facets of different paradigms of rangeland ecology. 
Contemporary policies towards pastoralism in rural China have multiple objectives (Addison and Greiner 2015). Generally, they aim is to improve both the environment and the livelihoods of pastoralists. They are designed to address the former by restoring grassland ecology, combatting desertification and reducing dust storms, and the latter by supplementing the incomes of herders and encouraging them away from traditional forms of extensive pastoralism. Central facets of these mandatory schemes for pastoralists include a shift towards exclusive user rights enforced by fencing, prescribed carrying capacities per hectare where grazing is allowed, and grazing bans elsewhere, with cash payments to compensate pastoral households, or to incentivise herd sizes being kept below set stocking rates.

There is no doubt that these schemes are significantly altering the livelihoods of a great many pastoralists living in China and that a critical aspect of these changes is a trend towards less mobility. Some have criticised the way in which the privatisation of grassland user rights has undermined the pastoral system's capacity to respond to drought and other adverse weather events through herd movement, increasing vulnerability to environmental change and resulting, as Li and Huntsinger (2011) suggest, in greater impoverishment and environmental deterioration. In some cases, these schemes have resulted in sedentary lifestyles in towns and cities through an associated resettlement policy frequently called 'ecological migration' (Yeh 2005). Ecological migration programmes have also affected pastoralists in other drylands in China, notably in Tibet where the goal is to move 100,000 herders off pastures to begin new lives in towns and cities (Wang et al. 2010b). Both Yeh and Wang et al. also note that the herders targeted by these ecological migration programmes are predominantly from ethnic minority groups.

Across the border in Mongolia, policies are also designed to address the issue of rangeland degradation (including dust storm prevention, although it is less of an issue than in China) and to improve the welfare of herders. Government in Mongolia is generally less interventionist since the collapse of socialism in the early 1990s, which resulted in the disappearance of local collectives-influenced by central government and preexisting customary institutions - that had previously allocated pastures and supported pastoralism through the provision of fodder, livestock, transport and veterinary services (Sneath 2003). Livestock were privatised with the transition to a market economy and nationally their numbers increased sharply, along with a general shift from sheep to goats, responding to growing international demand for cashmere. The increase in livestock numbers, particularly goats, is frequently cited as a major cause of desertification in Mongolia (Dorj et al. 2013), although many herders have suffered devastating losses during droughts and extreme winters (Sternberg 2010; Fernández-Giménez et al. 2012). One marked response to this situation has been a trend towards supporting localised forms of common property management by organising so-called community-based rangeland management (CBRM) groups with the goals of improving rangeland conditions and herder well-being. Many of these initiatives have received support from overseas development agencies and NGOs. However, the success of these CBRM groups in improving rangeland condition in the Mongolian Gobi is a matter for debate (Addison et al. 2013) and their social benefits are by no means clear-cut (Ulambayar et al. 2016).

The Mongolian government's Land Law, introduced in 1994 to fill the institutional land tenure vacuum resulting from the end of socialism, authorised contracts for pastoral resources such as pastures and campsites. However, the law's lack of clarity and its implementation at the local level have had a range of not always intended effects. Herders' user rights have often been sidelined by an expansion of minerals licensing across the countryside, leaving pastoralists seemingly powerless in the face of mining activities 
(Upton 2012). The Land Law has also affected herder mobility. Fernández-Giménez and Batbuyan (2004) concluded that the poor had become more mobile and the wealthy more sedentary due to changes in access to pastoral resources. Further evidence of declining mobility among herders in Mongolia for economic reasons has been presented by Lkhagvadorj et al. (2013), but it is not a central ambition of government to encourage herders to settle in the same way it is in China. Lkhagvadorj et al. (2013) suggest that reduced seasonal migrations have left herders more vulnerable to a shortage of fodder, a finding supported by Middleton et al. (2015) who highlight the consequences of such vulnerability during severe climatic events: loss of livestock on a sometimes large scale. Wesche and Retzer (2005) state that a nomadic way of life appears to be a "crucial precondition for sustainable land use' in the Gobi Desert steppes.

\section{Conclusions}

This paper investigates the links between dust storms, desertification, climate variability and pastoralism as an entry point for comparing policies for rangeland management in the Gobi Desert of Mongolia and China. It assesses the received wisdom that overgrazing of rangeland by pastoralists has been the most common cause of desertification on both sides of the border and concludes that the evidence supporting this link is not always convincing. Indeed, many of the issues pertaining to the desertification debate are surrounded by controversy and contradictory findings in this part of the world, as in others. Underlying many of these controversies is a fundamental tension between two alternative views of rangeland dynamics.

Policies towards using (or not using) the grassland resource in the Gobi Desert are substantially different either side of the political frontier between China and Mongolia. Whether deliberate or not, these contrasting policies appear to be driven in part by an adherence to, or at least an influence from, contrasting paradigms in our understanding of rangeland ecology.

China's rangeland policies represent an unambivalent example of management on the basis of carrying capacities and Clementsian succession theory. In order to tackle what are considered to be the unwanted outcomes of overstocking stemming from the classic Tragedy of the Commons, individual household tenure of grasslands has been introduced alongside degrees of restriction on grazing in certain areas deemed highly susceptible to desertification and dust storm generation. A notable effect of these policies is a marked move away from traditional mobile pastoralism.

In Mongolia, by contrast, although the same conceptual framework of stable-state rangelands and carrying capacity also holds considerable sway, the policies towards rangelands are markedly different. Prominent among these differences is a willingness to encourage the communal management of rangelands through pasture user groups. Government policies do not actively promote the sedentarisation of mobile herders, although there is some evidence to suggest that Mongolian pastoralists are becoming less mobile anyway due to land tenure and economic factors.

There are many nuances to the debate on the sustainability of pastoralism in drylands, and current thinking in rangeland ecology has it that most arid and semiarid rangelands encompass elements of both equilibrium and non-equilibrium approaches and that grazing and variable rainfall are both important drivers of vegetation dynamics on different temporal and spatial scales. However, the state of pastoralism either side of the political 
boundary between Mongolia and China is very different. In Mongolia, pastoralism continues to be backed by government policies because it is viewed as an enduring land use practice that is an essentially sustainable response to the highly variable natural environment, albeit that livestock dynamics follow the typically 'boom and bust' cycle in line with non-equilibrium theory.

In China, by contrast, traditional pastoralism is clearly viewed as unsustainable and in need of modernisation and is therefore unlikely to feature prominently in the 'new socialist countryside'.

Acknowledgments The author acknowledges the 'Gobi Hazards' project funded by the Leverhulme Trust as a central support for significant parts of this research. Fieldwork in China was supported financially by the International Science and Technology Cooperation Program of China (No. 2013DFA91700). Two anonymous reviewers also made some valuable comments.

Open Access This article is distributed under the terms of the Creative Commons Attribution 4.0 International License (http://creativecommons.org/licenses/by/4.0/), which permits unrestricted use, distribution, and reproduction in any medium, provided you give appropriate credit to the original author(s) and the source, provide a link to the Creative Commons license, and indicate if changes were made.

\section{References}

Addison J, Greiner R (2015) Applying the social-ecological systems framework to the evaluation and design of payment for ecosystem service schemes in the Eurasian steppe. Biodivers Conserv. doi:10.1007/ s10531-015-1016-3

Addison J, Friedel M, Brown C, Davies J, Waldron S (2012) The critical review of degradation assumptions applied to Mongolia's Gobi Desert. Rangeland J 34(2):125-137

Addison J, Davies J, Friedel M, Brown C (2013) Do pasture user groups lead to improved rangeland condition in the Mongolian Gobi Desert? J Arid Environ 94:37-46

Allen-Diaz B, Chapin FS, Diaz S, Howden M, Puigdefabregas J, Stafford Smith M (1996) Rangelands in a changing climate: impacts, adaptations and mitigation. In: Watson WT, Zinyowera MC, Moss RH, Dokken DJ (eds) Climate change 1995-impacts, adaptation and mitigation. Cambridge University Press, Cambridge, pp 131-158

Behnke RH, Scoones I, Kerven C (1993) Range ecology at disequilibrium: new models of natural variability and pastoral adaptation in African Savannas. Overseas Development Institute, London

Bilotta GS, Brazier RE, Haygarth PM (2007) The impacts of grazing animals on the quality of soils, vegetation, and surface waters in intensively managed grasslands. Adv Agron 94:237-280

Bory AJM, Biscaye PE, Grousset FE (2003) Two distinct seasonal Asian source regions for mineral dust deposited in Greenland (NorthGRIP). Geophys Res Lett 30(4):1167

Bristow CS, Drake N, Armitage S (2009) Deflation in the dustiest place on Earth: the Bodélé Depression, Chad. Geomorphology 105(1):50-58

Brotherson JD, Brotherson WT (1981) Grazing impacts on the sagebrush communities of central Utah. Great Basin Nat 41:335-340

Cao S (2008) Why large-scale afforestation efforts in China have failed to solve the desertification problem. Environ Sci Technol 42:1826-1831

Clements FE (1916) Plant succession: an analysis of the development of vegetation. Carnegie Institution of Washington, Washington DC

Dalintai B, Yanbo L, Jianjun C (2011) The Eurasian Steppe: history of utilization and policies on the rangeland. In: Fernández-Giménez ME, Wang X, Baival B, Klein J, Reid R (eds) Restoring community connections to the land. CABI, Wallingford, pp 51-68

Dengler J, Janišová M, Török P, Wellstein C (2014) Biodiversity of Palaearctic grasslands: a synthesis. Agric Ecosyst Environ 182:1-14

Derbyshire E, Meng X, Kemp RA (1998) Provenance, transport and characteristics of modern aeolian dust in western Gansu Province, China, and interpretation of the Quaternary loess record. J Arid Environ 39:497-516

Di Cosmo N (1994) Ancient Inner Asian nomads: their economic basis and its significance in Chinese history. J Asian Stud 53:1092-1126 
D'Odorico P, Okin GS, Bestelmeyer BT (2012) A synthetic review of feedbacks and drivers of shrub encroachment in arid grasslands. Ecohydrology 5(5):520-530

Dorj O, Enkhbold M, Lkhamyanjin S, Mijiddorj K, Nosmoo A, Puntsagnamil M, Sainjargal U (2013) In: Heshmati GA, Squires VA (eds) Mongolia: Country features, the main causes of desertification and remediation efforts. In combating desertification in Asia, Africa and the Middle East. Springer, Dordrecht, pp 217-229

Dorjsuren C, Sainbayar D (2004) Review of the a forestation and desertification control strategies in Mongolia. FAO, Ulaanbaatar

Endicott E (2012) A history of land use in Mongolia: the thirteenth century to the present. Springer, Berlin

Fan B, Guo L, Li N, Chen J, Lin H, Zhang X, Shen M, Rao Y, Wang C, Ma L (2014) Earlier vegetation green-up has reduced spring dust storms. Scientific reports 4:6749

Fernández-Giménez M, Allen-Diaz B (2001) Vegetation change along gradients from water sources in three grazed Mongolian ecosystems. Plant Ecol 157:101-118

Fernández-Giménez ME, Batbuyan B (2004) Law and disorder: local implementation of Mongolia's Land Law. Dev Change 35:141-166

Fernández-Giménez ME, Batkhishig B, Batbuyan B (2012) Cross-boundary and cross-level dynamics increase vulnerability to severe winter disasters (dzud) in Mongolia. Glob Environ Change 22:836-851

Fullen MA, Mitchell DJ (1994) Desertification and reclamation in north-central China. Ambio 23(2):131-135

Gillson L, Hoffman MT (2007) Rangeland ecology in a changing world. Science 1136577(53):315

Goudie A, Middleton N (2006) Desert dust in the global system. Springer, Berlin

Han JG, Zhang YJ, Wang CJ, Bai WM, Wang YR, Han GD, Li LH (2008) Rangeland degradation and restoration management in China. Rangeland J 30:233-239

Hein L (2006) The impacts of grazing and rainfall variability on the dynamics of a Sahelian rangeland. J Arid Environ 64:488-504

Hilker T, Natsagdorj E, Waring RH, Lyapustin A, Wang Y (2014) Satellite observed widespread decline in Mongolian grasslands largely due to overgrazing. Glob Change Biol 20(2):418-428

Hoffmann C, Funk R, Wieland R, Li Y, Sommer M (2008) Effects of grazing and topography on dust flux and deposition in the Xilingele grassland, Inner Mongolia. J Arid Environ 72:792-807

Huang CC, Pang J, Huang P, Hou C, Han Y (2002) High-resolution studies of the oldest cultivated soils in the southern Loess Plateau of China. Catena 47:29-42

Huang L, Xiao T, Zhao Z, Sun C, Liu J, Shao Q, Wang J (2013) Effects of grassland restoration programs on ecosystems in arid and semiarid China. J Environ Manag 117:268-275

Huho JM, Ngaira JK, Ogindo HO (2011) Living with drought: the case of the Maasai pastoralists of northern Kenya. Educ Res 2:779-789

Issanova G, Abuduwaili J, Galayeva O, Semenov O, Bazarbayeva T (2015) Aeolian transportation of sand and dust in the Aral Sea region. Int J Environ Sci Technol 12(10):3213-3224

Jeong S, Ho C, Brown M, Kug J, Piao S (2011) Browning in desert boundaries in Asia in recent decades. J Geophys Res. doi:10.1029/2010JD014633

Johansen JR, St. Clair LL (1986) Cryptogamic soil crusts: recovery from grazing near Camp Floyd State Park, Utah, USA. Great Basin Nat 46:632-640

Johnson DA, Sheehy DP, Miller D, Damiran D (2006) Mongolian rangelands in transition. Sécheresse 17:133-141

Joly F, Saïdi S, Begz T, Feh C (2012) Key resource areas of an arid grazing system of the Mongolian Gobi. Mong J Biol Sci 10(1-2):13-24

Jones A (2000) Effects of cattle grazing on North American arid ecosystems: a quantitative review. West $\mathrm{N}$ Am Nat 60(2):155-164

Kashima S, Yorifuji T, Bae S, Honda Y, Lim YH, Hong YC (2016) Asian dust effect on cause-specific mortality in five cities across South Korea and Japan. Atmos Environ 128:20-27

Khishigbayar J, Fernández-Giménez ME, Angerer JP, Reid RS, Chantsallkham J, Baasandorj Y, Zumberelmaa D (2015) Mongolian rangelands at a tipping point? Biomass and cover are stable but composition shifts and richness declines after 20 years of grazing and increasing temperatures. J Arid Environ 115:100-112

Kim J (2008) Transport routes and source regions of Asian dust observed in Korea during the past 40 years (1965-2004). Atmos Environ 42(19):4778-4789

Kurosaki Y, Shinoda M, Mikami M (2011) What caused a recent increase in dust outbreaks over East Asia? Geophys Res Lett 38:L11702

Lamprey HF (1983) Pastoralism yesterday and today: the overgrazing problem. In: Bourlière F (ed) Tropical savannas: ecosystems of the world. Elsevier, Amsterdam, pp 643-666

Lattimore O (1938) The geographical factor in Mongol history. Geogr J 91:1-16 
Lee EH, Sohn BJ (2011) Recent increasing trend in dust frequency over Mongolia and Inner Mongolia regions and its association with climate and surface condition change. Atmos Environ 45:4611-4616

Lei DE, Shangguan ZP, Rui LI (2012) Effects of the grain-for-green program on soil erosion in China. Int J Sediment Res 27:120-127

Li W, Huntsinger L (2011) China's grassland contract policy and its impacts on herder ability to benefit in Inner Mongolia: tragic feedbacks. Ecol Soc 16(2):1

Liu YY, Evans JP, McCabe MF, de Jeu RAM, van Dijk A, Dolman AJ, Saizen I (2013) Changing climate and overgrazing are decimating Mongolian steppes. Plos One 8(2):e57599

Liu Q, LiuY Yin J, Zhang M, Zhang T (2014) Chemical characteristics and source apportionment of PM 10 during Asian dust storm and non-dust storm days in Beijing. Atmos Environ 91:85-94

Lkhagvadorj D, Hauck M, Dulamsuren Ch, Tsogtbaatar J (2013) Pastoral nomadism in the forest-steppe of the Mongolian Altai under a changing economy and a warming climate. J Arid Environ 88:82-89

Lund HG (2007) Accounting for the world's rangelands. Rangelands 29:3-10

Matches AG (1992) Plant response to grazing: a review. J Prod Agric 5:1-7

McLeman RA, Dupre J, Ford LB, Ford J, Gajewski K, Marchildon G (2014) What we learned from the Dust Bowl: lessons in science, policy, and adaptation. Popul Environ 35(4):417-440

McNaughton SJ (1983) Compensatory plant growth as a response to herbivory. Oikos 40:329-336

McTainsh G, Chan YC, McGowan H, Leys J, Tews K (2005) The 23rd October 2002 dust storm in eastern Australia: characteristics and meteorological conditions. Atmos Environ 39:1227-1236

Middleton N (1985) Effect of drought on dust production in the Sahel. Nature 316:431-434

Middleton N (2009) Deserts: a very short introduction. Oxford University Press, Oxford

Middleton N, Sternberg T (2013) Climate hazards in drylands: a review. Earth-Sci Rev 126:48-57

Middleton N, Thomas D (1997) World atlas of desertification, 2nd edn. Arnold, London

Middleton N, Stringer L, Goudie A, Thomas D (2011) The forgotten billion: MDG achievement in the drylands. UNDP-UNCCD, New York

Middleton N, Rueff H, Sternberg T, Batbuyan B, Thomas D (2015) Explaining spatial variations in climate hazard impacts in western Mongolia. Landsc Ecol 30(1):91-107

Milchunas DG, Lauenroth WK (1993) Quantitative effects of grazing on vegetation and soils over a global range of environments. Ecol Monogr 63(4):327-366

Mühlenberg M, Batkhishig T, Dashzeveg T, Drößler L, Neusel B, Tsogtbaatar J (2006) Lessons from tree planting initatives in Mongolia. Mongolia Discussion Papers, East Asia and Pacific Environment and Social Development Department. World Bank, Washington DC

Nicholson SE, Tucker CJ, Ba MB (1998) Desertification, drought, and surface vegetation: an example from the West African Sahel. Bull Am Meteorol Soc 79:815-829

Piao S, Fang J, Liu H, Zhu B (2005) NDVI-indicated decline in desertification in China in the past two decades. Geophys Res Lett. doi:10.1029/2004GL021764

Piao S, Fang J, Friedlingstein P, Ciais P, Viovy N, Demarty J (2007) Growing season extension and its impact on terrestrial carbon cycle in the northern hemisphere over the past 2 decades. Glob Biogeochem Cycles 21:GB3018. doi:10.1029/2006GB002888

Prospero JM, Ginoux P, Torres O, Nicholson SE, Gill TE (2002) Environmental characterization of global sources of atmospheric soil dust identified with the NIMBUS-7 TOMS absorbing aerosol product. Rev Geophys 40(1): 1002

Qi F, Wei L, Haiyang X (2013) Comprehensive evaluation and indicator system of land desertification in the Heihe River Basin. Nat Hazards 65:1573-1588

Qu F, Kuyvenhoven A, Shi X, Heerink N (2011) Sustainable natural resource use in rural China: recent trends and policies. China Econ Rev 22(4):444-460

Regdel D, Dugarzhav C, Gunin P (2012) Ecological demands on socioeconomic development of Mongolia under climate aridization. Arid Ecosyst 2:1-10

Reid RS, Fernández-Giménez ME, Galvin KA (2014) Dynamics and resilience of rangelands and pastoral peoples around the globe. Annu Rev Environ Resour 39:217-242

Retzer V (2006) Impacts of grazing and rainfall variability on the dynamics of a Sahelian rangeland revisited-new insights from old data. J Arid Environ 67:157-164

Rowntree K, Duma M, Kakembo V, Thornes J (2004) Debunking the myth of overgrazing and soil erosion. Land Degrad Dev 15(3):203-214

Safriel U, Adeel Z, Niemeijer D, Puigdefabregas J, White R, Lal R, Winslow M, Ziedler J, Prince S, Archer E, King C (2005) Chapter 22: dryland systems. Millennium Ecosystem Assessment. Ecosystems and human well-being. World Resources Institute, Washington DC, pp 623-662

Sasaki T, Okayasu T, Jamsran U, Takeuchi K (2008) Threshold changes in vegetation along a grazing gradient in Mongolian rangelands. J Ecol 96:145-154

Shao Y, Wang J (2003) A climatology of Northeast Asian dust events. Meteorol Z 12(4):187-196 
Shinoda M, Gillies JA, Mikami M, Shao Y (2011) Temperate grasslands as a dust source: knowledge, uncertainties, and challenges. Aeolian Res 3(3):271-293

Skidmore EL (1986) Wind erosion control. Clim Chang 9:209-218

Sneath D (2003) Land use, the environment and development in post-socialist Mongolia. Oxford Dev Stud 31(4):441-459

Sternberg T (2010) Unravelling Mongolia's extreme winter disaster of 2010. Nomad People 14:72-86

Sternberg T, Rueff H, Middleton N (2015) Contraction of the Gobi Desert, 2000-2012. Remote Sens 7:1346-1358

Stumpp M, Wesche K, Retzer V, Miehe G (2005) Impact of grazing livestock and distance from water points on soil fertility in southern Mongolia. Mt Res Dev 25:244-251

Su H, Liu W, Xu H, Wang Z, Zhang H, Hu H, Li Y (2015) Long-term livestock exclusion facilitates native woody plant encroachment in a sandy semiarid rangeland. Ecol Evol 5(12):2445-2456

Tan M, Li X (2015) Does the Green Great Wall effectively decrease dust storm intensity in China? A study based on NOAA NDVI and weather station data. Land Use Policy 43:42-47

Tegen I, Lacis A, Fung I (1996) The influence of mineral aerosols from disturbed soils on the global radiation budget. Nature 380:419-422

Tucker C, Dregne H, Newcomb W (1991) Expansion and contraction of the Sahara Desert from 1980 to 1990. Science 253:299-301

Ulambayar T, Fernández-Giménez ME, Baival B, Batjav B (2016) Social outcomes of community-based rangeland management in Mongolian steppe ecosystems. Conserv Lett. doi:10.1111/conl.12267

Upton C (2012) Mining, resistance and pastoral livelihoods in contemporary Mongolia. In: Dierkes J (ed) Change in Democratic Mongolia: social relations, health, mobile pastoralism, and mining (vol 25). Brill, Leiden, pp 223-248

Vetter S (2005) Rangelands at equilibrium and non-equilibrium: recent developments in the debate. J Arid Environ 62:321-341

Wang X, Dong Z, Zhang J, Liu L (2004) Modern dust storms in China: an overview. J Arid Environ 58:559-574

Wang X, Chen F, Hasi E, Li J (2008) Desertification in China: an assessment. Earth-Sci Rev 88:188-206

Wang X, Zhang C, Hasi E, Dong Z (2010a) Has the Three Norths Forest Shelterbelt Program solved the desertification and dust storm problems in arid and semiarid China? J Arid Environ 74:13-22

Wang Z, Song K, Hu L (2010b) China's largest scale ecological migration in the three-river headwater region. Ambio 39:443-446

Wesche K, Retzer V (2005) Is degradation a major problem in semi-desert environments of the Gobi region in southern Mongolia. Erforschung Biologischer Ressourcen der Mongolei 9:133-146

WISP (World Initiative for Sustainable Pastoralism) (2008) Forgotten Services, Diminished Goods: understanding the agroecosystem of pastoralism. WISP Policy Note 8

Wu Z, Wu J, Liu J, He B, Lei T, Wang Q (2013) Increasing terrestrial vegetation activity of ecological restoration program in the Beijing-Tianjin sand source region of China. Ecol Eng 52:37-50

Yang X, Zhang K, Jia B, Ci L (2005) Desertification assessment in China: an overview. J Arid Environ 63:517-531

Yatagai A, Yasunari T (1995) Interannual variations of summer precipitation in the arid/semi-arid regions in China and Mongolia: their regionality and relation to the Asian summer monsoon. J Meteorol Soc Jpn Ser 2(73):909-923

Yeh ET (2005) Green governmentality and pastoralism in western China: 'converting pastures to grasslands'. Nomad People 9:9-30

Zemmrich A (2007) Equilibrium or non-equilibrium ecosystems? Scaling effects in rangeland ecosystems of western Mongolia. Erdkunde 61:335-343

Zhang XY, Gong SL, Zhao TL, Arimoto R, Wang YQ, Zhou ZJ (2003) Sources of Asian dust and role of climate change versus desertification in Asian dust emission. Geophys Res Lett 30(24):2272

Zhang B, Tsunekawa A, Tsubo M (2008) Contributions of sandy lands and stony deserts to long-distance dust emission in China and Mongolia during 2000-2006. Glob Planet Change 60(3):487-504

Zhang Y, Peng C, Li W, Tian L, Zhu Q, Chen H, Fang X, Zhang G, Li G, Mu X, Li Z (2016) Multiple afforestation programs accelerate the greenness in the 'Three North' region of China from 1982 to 2013. Ecol Ind 61:404-412

Zhao H-L, Zhao X-Y, Zhou R-L, Zhang T-H, Drake S (2005) Desertification processes due to heavy grazing in sandy rangeland, Inner Mongolia. J Arid Environ 62:309-319

Zhu C, Wang B, Qian W (2008) Why do dust storms decrease in northern China concurrently with the recent global warming? Geophys Res Lett 35(18):L18702 